\title{
MISSING CADRES? \\ List Voting and the ANC's Management of its \\ Parliamentarians in the National Assembly, 1999-2003
}

\author{
By
Geoffrey Hawker
}

Geoffrey Hawker is Senior Lecturer in the Department of Politics and International Relations, Macquarie University, NSW 2109 Australia;

Tel: +6129850 8885; Fax: + 6129850 6064;

e-mail: Geoffrey.hawker@mq.edu.au

\section{INTRODUCTION}

The party list system of voting can give a dominant party undue influence over its parliamentary members, critics say, instancing the practices of the African National Congress (ANC) in South Africa's National Assembly. The party has defended its use of the system and the 'redeployments' it permits as necessary to its program of reconstruction; claiming a right to use scarce human resources, including parliamentarians, in new positions as circumstances change.

Since 1999 the Assembly has seen high rates of turnover and deployments of varying character, and the evidence suggests that the management of its parliamentary members challenges the capacity of the ANC. Lines of gender and provincial representation structure the party's choices, raising issues of representation and accountability. A review of the careers of the sixty members who ceased to be members of the Assembly after the election of 1999 shows that the list system is only one factor to be considered in assessing the internal democracy of the ANC and its policies in Parliament and in government.

\section{THe List SYSTEM OF Voting}

Commentators have identified the party list system of voting as a key mechanism influencing political development in South Africa - very negatively, according to most. While the linked but distinct method of proportional representation also adopted in South Africa has strong supporters as well as opponents (Reynolds 1999, pp 97-101; Pottie 2001, pp 33-35; Southall 2001, pp 275-76 and 2003, p 129; Giliomee, Myburgh and Schlemmer 2001, pp180-81), the list system has few supporters beyond the dominant party, the ANC.

Though the party originally favoured a constituency-based system (Pottie, pp 30-31; Reynolds, pp 183-87), it found in office that the list system allowed it to 
choose, move and remove parliamentary representatives in convenient ways that, it is said, flout norms of responsibility and accountability between representatives and electors and devalue parliamentary activity when members whose careers rest with the party become mere 'lobby fodder' (Southall 2000, p 158 and 1998, p 448). The system 'constrains the free flow of changing opinion in a democracy (Kotze 2001, p $40)^{\prime}$. Members, without a base in a constituency 'have little incentive ... to champion any cause which may run counter to party policy or practice (Bridgman 2002, p 72)'. The system has 'allowed the ANC to effectively close down dissent within the party' and has 'effectively marginalised Parliament' (Giliomee, Myburgh and Schlemmer, p 173; see also Adam, Slabbert and Moodley, pp 86-88).

The system works best for a party when it has a dominant share of the fruits of politics. Then, as with the ANC, it is said, the lists can be used to 'park' members who are really on their way to other jobs and to entice others with opportunities that diminish their independence. The result of the recent period of floor-crossing from March 2003 (a temporary cessation of party discipline to 'encourage' members to move to other parties in national and provincial assemblies) was lamentable but predictable: nine recruits to the ANC in the Assembly, securing the constitutional majority of two-thirds just missed in the June 1999 election, and not a single loss anywhere in the provinces, so that the party has majorities in the last 'provinces of opposition' - the Western Cape and KwaZulu- Natal (Idasa 2003). The worst result might be that the opposition parties become ever more fragmented and polarised on racial lines and that a dominant ANC risks fracture within more than challenge without.

Though the list system, or its use, may have a lot to answer for, the broader political strategies guiding its use have been defended by the ANC, especially in the policies on cadre deployment adopted at the Kwabwe conference of 1985 and reaffirmed and extended at the national conference of 1997 (gopher:// gopher.anc.org.za:70/00/anc/history/kabcadre.txt 2000, pp 1-32; Sechaba1985, p 14 cf. Giliomee, Myburgh and Schlemmer, pp 170-174). The other parties with a presence at both national and provincial levels after 1994 - the Inkatha Freedom Party (IFP), the Democratic Party (DP), and the (New) National Party - have also used the list system to 'deploy' members, but might be thought merely to be following the dominant ANC in practice if not in philosophy.

In the ANC the deployment of parliamentarians was seen as part of a broader strategy of institutional change, achieved through the positioning of members in key positions in the public and private sectors and requiring mobility in individuals as circumstances changed. Elected representatives were special, but accountability was achieved by a better defined place for the Parliament within the polity and by a parliamentary membership that adhered to new norms of representation in race, sex and place - those values instilled in the 'Chapter Nine' institutions of the Constitution that balanced both Parliament and Presidency (Nijzink 2001, p 59; Southall 2000, pp 161-63). Government was conditional on control of Parliament by the ruling party, and the legitimacy of the party was attested in free and fair elections. 
Within this context - management of the list system having produced an increased majority in 1999 and since - it is not surprising that the ANC is reluctant to attend to the campaign by the Democratic Party and others for a changed system of voting. Our review suggests, however, that the ANC has also experienced great difficulty in operating the list system effectively and that troublesome issues in managing its parliamentarians may tempt it to 'reform' this aspect of the 'rules of the game'.

\section{The National Assembly 1999}

An examination of the ANC's management of its 266 members in the National Assembly, from Vice-President Jacob Zuma down, in the period from the election of June 1999 to mid-2003, shows that the movement of members in and out of the Assembly was, by any standards, frequent. Whether it is a sign of deployment at work or a possibly corrupt management of resources, or merely chaotic politics, has to be determined. Although answers for the whole range of positions open to deployment might potentially involve many institutions, there is no doubt that the Assembly is the central locale of deployment and must reflect and shape the whole. Of the original 266 members of June 1999, sixty (22.6\%) were no longer members by May 2003, including the last exclusion of prominence - Winnie MadikizelaMandela - whose appeal against a conviction for financial offences was pending in mid-2003. From 2000 there were numerous resignations and redeployments connected with the 'arms deal', and these and other cases are considered below. Given the likely continuing turnover of members by the time of the next election (April 2004) the party will likely have lost some $30 \%$ of its parliamentarians since the last.

This is probably a high figure even for parliaments with a list system, but might be explained in part by the strains of establishing a new system of government after the transition of 1994 (Southall 2000, pp 149-51). A comparison of the published lists shows that of the 252 ANC members elected to the first Assembly, only 130, or barely half, were elected in the following election, though half a dozen others later re-entered the Assembly as replacements for members elected in 1999. Allowing for the fact that some members who do survive until the next election will not, for one reason or another, be re-listed or re-elected, it is possible for the rate of turnover of ANC Parliamentarians to increase further.

\section{The Parliamentary Institution}

Would it matter (a distant prospect though not inconceivable) if only a minority of ANC parliamentarians elected at an election survived their full term? An answer might only be as important as the parliamentary institution itself, which is not the all-powerful body of the apartheid regime, based on English notions of parliamentary sovereignty, when 'the will of a racially-exclusive Parliament was ... 
paramount' (Klug 2000, p 35) and cloaked the real power of the state president, elected not directly but by the Parliament. The ANC asserted anew the power of the political party over the institutions of the state, and the 'centralisation of power under Mbeki' (Southall 2000, p 157) might seem to settle the issue. The President, who is not a Member of Parliament (though initially elected as one), chooses the Cabinet (which may, according to s 91(3)c of the Constitution Act, only include two extra-parliamentary members) and appears in Parliament by choice. Despite Mbeki's executive tendencies, he seems more interested in the Parliament than was Mandela, whose practice it was to address Parliament at its opening and during the finance debate. Mbeki has also experimented with attendance at question time, at the launch of the New Partnership for Africa's Development (Nepad) and at the reception of the final Truth and Reconciliation Commission (TRC) report.

Mbeki's position is, indeed, ambiguous. The South African system of government has been variously classified as based on 'plurality election' or 'majority rule', but definitely not on 'direct presidential election' (Blais, Massicotte and Dobrzynska 1997, pp 444-45.); as 'semi-presidential' (Southall 2000, p156); as 'a combination of semi-presidentialism with parliamentarianism' (Lane and Ersson 1997, cited in Southall 2000, p 168); and as 'Parliamentary government headed by a prime minister ...[with] the title of state president' (Reynolds, p 129). The last seems over stated, but the eschewal generally of simple notions of 'presidentialism' seems well established, even if the place of Parliament is disputed.

At issue is the unique way in which the succession of offices linking Parliament and the executive presidency is defined in the constitutional arrangements enacted in 1996. The African nations of the first wave of independence claimed a directly elected presidency separate from the elected parliament as a foremost achievement - remembered was Nkrumah's movement to true independence less than a year after the British left by 'taking office as executive president of the nation, head of state as well as of the government' (Nkomo1984, p 75). Remembered, too, was a tendency to 'descend' into the 'African pattern' of one-party rule and uncurbed presidential power' (Pottie, p 25).

South Africa's 'second wave' of 1994 adopted a different method. It was distinctly 'parliamentary', as the office of President was filled by the parliamentary nomination of the top-listed candidate of the dominant party in the Assembly. The President can be said to be popularly and directly elected, but only as the leading candidate on a parliamentary slate. Necessarily Mbeki was the ANC's first retirement from the National Assembly, immediately on taking office as President. His successor, businessman E P Mogale, had been just below the 'cut' on the national list at the election. Reflecting the politics of the Alliance that had built the list, he was a member of the South African Communist Party (SACP), and, as it happened, was, a few months later, also replaced.

The issue is less whether Parliament is an institution with certain powers in the processes of accountability (through committee activity for instance) than whether processes of accountability exist within the parties and take shape in intra- 
party dispute between members in the parliamentary institution. It is important whether 'the task of criticism rests not only with opposition political parties but also with dissident elements within the ruling party' (Southall 2003, p 19), and important whether the dissidence is parliamentary, at least in important aspects. Mbeki's replacement by Mogale was a formality, but later replacements did not necessarily adhere to the list as presented to the electors in June 1999, and the extent to which the pattern of deployments and replacements reflected internal struggle in the party is considered below. ${ }^{1}$

In the period since 1999 there seems no doubt that testing questions have arisen in Parliament about the 'arms deal', when the government's decision, initially secret, to spend (as was claimed later) some R30b on arms purchases unapproved by Parliament, led to criticism by the Auditor General and to a critical report by the Standing Committee on Public Accounts, chaired in the Westminster tradition by an opposition party member (Gavin Woods, IFP). Accused of benefiting personally were ANC government members (Ben Modise, Tony Yengeni) or officials (the most important of whom is Chippy Shaik of the Defence Department). The majority ANC bloc on the committee, under Andrew Feinstein, supported or initiated further inquiry, but denied one aspect - the proposed involvement of former judge Willem Heath after the proposal that he be included had received a strong presidential rebuke. A number of resignations and 'redeployments' took place in relation to these issues. Among them was the resignation of ANC Chief Whip, Tony Yengeni, who was sentenced to a prison term for offences related to the 'arms deal'. Feinstein claimed that 'it had become increasingly difficult, if not impossible, for independentminded MPs to work for the ANC in Parliament' and that he was concerned 'about our accountability mechanisms in Parliament'. Though he intended to remain a member of the party, he would 'not hesitate to criticise when appropriate' (Mail $\mathcal{E}$ Guardian 31 August 2001). It is probable that not all the outcomes are yet apparent, but it is certain that issues of presidential and parliamentary power have sharpened rather than settled and that investigation of the 'arms deal' is unfinished.

The ANC's own professed standards provide a context within which to evaluate recent events. This is not to prepare a case for the defence, as it were, but to point to procedural norms and rules, expressing political struggle, that constrain the political party that has adopted them, at least partly for inspection by the 'international community'. Our focus is on the representation of place and gender in the ANC's members in the period since 1999, and the connected issue of the movements (deployments?) of those who, for one reason or another, had left the Assembly well before the election due in 2004. The size and structure of the caucus informs this discussion.

The term 'ANC member' is used throughout to cover affiliates of the ANC's partners in the Tripartite Alliance - the Congress of South African Trade Unions (Cosatu) and the SACP - as all run on a consolidated list under the ANC banner, with positions on the list reflecting relative voting strengths and negotiations between the partners. 


\section{The Party in Parlanent}

The 266 members of the ANC in the 400-member Assembly are relatively very dominant in comparison with other legislatures, and the size of the ANC caucus absolutely and relatively is very large - fewer than the 410 members of the Labour Party in the House of Commons, but more than the 229 Republicans in the US House of Representatives, say, and many more than the biggest political formation in the country previously - the 150 or so members of the old National Party in the House of Assembly in the closing years of the apartheid regime. Elsewhere in Africa, the government of Nigeria now also has more than 200 members in the lower house, but the ANC exercises more centralised control over the provinces of South Africa, which provided, in 1999, a further 234 provincial members, making the ANC's 'management' of over 500 active parliamentarians surely a considerable task.

The party acknowledged severe problems at its conference in December 2002 when it questioned whether the resources of the country could really afford such 'direct democracy' (ANC 10 May 2003). A reduction of the Assembly to 350 (as provided in the Constitution) was mooted, with proportional cuts in the provinces. 'Deployment committees' existed at national and provincial level but 'tensions and factionalism' made their functioning 'highly uneven' (ANC 7 May 2003, p 5). The party conceded that it needed 'to address the problem of some cadres not understanding that previous deployment (as a Cabinet minister, MEC [Member of a provincial executive council], mayor, etc) does not mean automatic deployment into that position or one of equivalent stature and financial package in subsequent elections' (ANC 2003).

The 'central organs' of the ANC have committed the party's most valuable human resources (the senior members of the party, including the President) to the parliamentary institution. This can be seen most clearly in the placing of the members of the National Executive Committee (NEC), the party's senior elected body. The occupational positions or deployments of its sixty members are summarised in Table 1. The NEC's non-elected components of ex-officio members (the leagues and the provincial parties) and observers, a mixed and changing group, have their role to play, but it is the capacity to win election to the central body that makes deployment at a certain level significant.

The lonely position in recent years of Mathews Phosa, the former Mpumalanga Premier, in opposition to Mbeki, need not suggest that the NEC is a united body around the President, but the 'deployment' of the others can be read directly from their seniority in the party. Party and executive offices are important, with Frank Chikane, Mbeki's head of office, the most senior of the non-Parliamentary 'deployments', elected, at eighteenth place, to the NEC. Some distancing of NEC members from senior positions in state organisations seems to be accepted; former ministers Tito Mboweni and Gill Marcus, for example, resigned from the NEC when they were deployed to the Reserve Bank as, respectively, Governor and Deputy Governor. Diplomatic postings (Jessie Duarte and Thenjiwe Mtintso), in contrast, 
Table 1

NEC Deployments

\begin{tabular}{|c|c|}
\hline ELECTED OFFICE & \\
Nat Assembly & 34 \\
NCOP & 1 \\
MECs & 7 \\
Premiers & 3 \\
Mayors & 2 \\
\hline PARTY ORGANS & 4 \\
Mbeki/Zuma offices & 3 \\
ANC offices & 3 \\
\hline BUSINESS \& DIPLOMACY & 2 \\
Business & 1 \\
Diplomacy & 60 \\
\hline NOT DEPLOYED & 3 \\
\hline TOTAL & \\
\hline
\end{tabular}

can evidently be held by current members of the NEC, and there is no prohibition on NEC members being 'deployed' to business, though few of them have been (cf Adams et al).

The choice of (deployment to) direct electoral politics is overwhelming, whatever the nuance of conflict and compromise in each case. Our concern is with the largest single group, the members of the Assembly, whose importance lies in more than mere numbers, as note of the other deployments shows. The presence of mayors (none was in the NEC of 1994 and only one in 1999) shows the party's increased interest in large metropolitan agglomerations of local authorities, set against its continuing scepticism about the capacity of provincial government to follow central leadership. But provincial structures will take time to unravel, if ever they do, not least because the ANC has entrenched some procedural aspects of provinciality in the party (Southall 2001). Thus the deployment of NEC members to provincial parliaments as MECs may seem simply to be a manifestation of the party's desire to get the best from a working system while thinking actively, if thus far unsuccessfully, about mechanisms of changing it. The balance of appointments shows that more than central power is at work, however. No province has more than one NEC member assigned to it, and the cabinets of three provinces (Free State, North West and Western Cape) do not contain a NEC member at all. The 
pattern reflects the local power bases of key individuals and, in the case of the Free State at least, a tendency to let the provincial party 'sort itself out'.

The presence of premiers can be taken for granted even less. It is not that four of the seven ANC premiers are missing from the NEC, but that three have been able to win election to it in their own right. Until 1999, the ANC enforced the rule that premiers could only be ex-officio members of the NEC, stressing the subordination of that level of government within party structures by quarantining the individuals in office. The relaxation of the rule for three strong premiers (Manne Dipico, Northern Cape; Ngoako Ramatlhodi, Limpopo and Popo Molefe, North West - the last two in some conflict with the presidency in their governmental roles) may suggest that a 'provincial power base' can now be tolerated to some degree within an NEC otherwise resolutely 'national'.

Those in business (Cyril Ramaphosa, 'Saki' Macozoma, Max Sisulu), and the diplomatic postings, show accommodations to preserve the capacity of the individuals concerned while detaching them from the run of daily consultation of the core which, in the normal course of the parliamentary year, largely takes place in and around the parliamentary and executive offices in Cape Town.

The overwhelming preference of the leading cadres for national activity within a parliamentary framework is obvious. More than half the NEC is deployed to the Assembly, occupying about one-eighth of the caucus but virtually exclusively the most senior positions in and near the Cabinet. (The relative importance of the National Council of Provinces [NCOP] is also revealed.) The twenty most senior members of the NEC are in the Assembly as Cabinet ministers, with the exceptions only of Chikane and Cyril Ramaphosa and, until her recent exclusion from the NEC and Parliament, Winnie Madikizela-Mandela.

From the 'parliamentary side', it seems important that all Cabinet ministers are members of the NEC, with the single exception pointing to a rule that the ANC has bound itself to. The Minister of Sport, Ngconde Balfour, failed to win election to the NEC in 1997 but was appointed to Cabinet and brought into the NEC with observer status, confirmed after the 2002 conference. A precedent had been set in the case of Minister of Public Works Stella Sigcau, a NEC member until 1997 and from 2002, who maintained her ministerial position throughout and was an observer on the NEC during the period when she was not a member. Deputy ministers are drawn from both NEC and non-NEC members and from members of national and provincial lists, which serves to underline the distinctive nature of the Cabinet's membership and accountability. In practice the President has the freedom to coopt one Cabinet member beyond the NEC, and any extension of that number would have an obvious significance.

\section{Party Structure in Parliament}

During elections separate ballot papers are used to vote for the national and for the provincial assemblies. Equally important is the differences within the national ballot 
which consists of two lists - one national and one provincial - each potentially generating 200 members, or half the total membership of the Assembly. These national and provincial lists distinguish ' $\mathrm{A}$ ' and ' $\mathrm{B}$ ' teams in ways that are central to the system of accountability the ANC attempts to achieve. Table 2 summarises the occupancy of parliamentary posts, defined by seniority as Cabinet ministers, deputy ministers, committee chairs and whips, and backbenchers, by national and provincial lists.

Table 2

Seniority by National and Provincial Lists

\begin{tabular}{|c|c|c|c|c|c|}
\hline & \multicolumn{3}{|c|}{ NATIONAL } & \multicolumn{2}{|c|}{ PROVINCIAL } \\
\hline & Number & $\%$ & Number & $\%$ & Total number \\
\hline Cabinet Ministers & 27 & 100 & 0 & 0 & 27 \\
\hline Deputy Ministers & 6 & 60 & 4 & 40 & 10 \\
\hline Committee chair, whip & 26 & 51 & 25 & 49 & 51 \\
\hline \multirow[t]{2}{*}{ Backbench } & 68 & 38 & 110 & 62 & 178 \\
\hline & 127 & & 139 & & 266 \\
\hline
\end{tabular}

The ANC is a centralising party, and accepted most reluctantly the quasi-federalism of regional government. Yet a commitment to programs of equality in social and political dimensions, centrally determined, implies a geographical and spatial indifference (or affirmative action for oppressed areas) and a capacity to represent all regions of the country as eventually agreed in an 'equal' way. The NCOP was the chief recognition of that in an institutional sense, but the membership of the party in the Assembly shows similarly how a provincial orientation can be organised to be subordinate but can also be compensated and entrenched to some degree. Following Faure, Pottie has noted that a provincial list 'conforms to elements of proposals for multi-member electoral districts, albeit very large ones' (Pottie, p 32). Although almost half the national list is on or near the front bench only one in five provincial members occupies this position. Some advancement for the latter comes in positions as whips and committee chairs, and the movement to the deputy ministry has accelerated to four from a single position in 1994. But a near limit at that level has been reached, and that is as far as a provincial list MP can go. Entry to Cabinet during the term of a Parliament would require movement or 'redeployment' to a place on the national list, an unthinkable move in light of the convention outlined here, implying incapacity in the national membership. The movement of members in this way would be possible, however, during an election period as the party list is formed. 
Though membership of the Cabinet is effectively restricted to half the caucus, the dividing line between national and provincial lists is, in another way, deliberately blurred or re-defined in order to preserve provincial interests. That is, provincial representation is higher because of the ANC's management of the list system than a strict application of proportionality - the declared basis of the voting system might allow. Though the A and B teams are, in principle, equal in number (133 each), in 1999 the national list was trimmed, and provincial representation augmented, by six positions, allowing a re-adjustment of the numbers in all provincial sets of members to reflect the vote of the ANC in each. The Western Cape and KwaZulu-Natal shed a nominal fifteen posts to the provinces with a better ANC vote, especially the Eastern Cape (4) and Limpopo (3). Such trimming was evident also in other parties with national and provincial representation and has been reported as a puzzling feature of the parliamentary count of numbers in South Africa (Carr 21 July 2003).

These were, to be sure, accretions and movements in the deepest backbench. Members drawn from the party's national list held all the important Assembly posts, and, exclusively, the Cabinet positions. They were elected to positions on the party list by proportionality of voting through party branches and associated organs, without regard, it was said, to race or region - 'an admirably democratic nomination process' (Adam, Slabbert and Moodley, p 87). The party executive certainly modified the lists, most justifiably no doubt to comply with the mandated issue of female representation, but national members were 'national', and not 'provincial' or regionally tied. In outcome, however, the leading group was also a distorted reflection of the party's vote, as its members were drawn most disproportionately across the provinces. The relationship between the party's mass vote and its leadership vote was almost inverse, as Table 3 shows.

Table 3

ANC Voting - Mass and National List Positions

\begin{tabular}{|c|l|c|c|c|l|c|c|}
\hline Rank & Province & Mass vote & \% Nat. tot. & Rank & Province & Nat. list $\%$ & Nat tot \\
\hline 1 & Gauteng & 2486938 & 20.3 & 1 & W Cape & 34 & 26.8 \\
2 & E Cape & 2411695 & 19.8 & 2 & Gauteng & 28 & 22.0 \\
3 & Limpopo & 1780177 & 14.5 & 3 & KZN & 18 & 14.2 \\
4 & N West & 1325559 & 10.8 & 4 & Free State & 13 & 10.2 \\
5 & KZN & 1185669 & 9.7 & 5 & E Cape & 10 & 7.9 \\
6 & Mpumalanga & 1072518 & 8.8 & 6 & N West & 8 & 6.3 \\
7 & Free State & 1059313 & 8.7 & 7 & N Cape & 7 & 5.5 \\
8 & W Cape & 714271 & 5.8 & 8 & Mpuma & 5 & 3.9 \\
9 & N Cape & 201515 & 1.6 & 9 & Limpopo & 4 & 3.1 \\
\hline & & $\mathbf{1 2} 237 \mathbf{6 5 5}$ & $\mathbf{1 0 0 . 0}$ & & & $\mathbf{1 2 7}$ & $\mathbf{1 0 0 . 0}$ \\
\hline
\end{tabular}


The ANC draws its voting strength from the north and the east, but members who live and have a political base elsewhere hold most of the leading positions in the party. The Eastern Cape and Limpopo provide more than a third of the vote but barely $10 \%$ of the leadership. Gauteng, KwaZulu-Natal and the Free State provide somewhat more than their notional share, but it is the Western Cape (with less than $6 \%$ of the total ANC vote in 1994) that provides fully a quarter of the leadership - a representation that carries through to Cabinet, where six ministers are identified with the province.

The national list is decidedly 'non-provincial' in its ostensible orientation, and its national mission is defined against certain 'provincial guarantees', some described here. However, the leadership of the party also draws on specificities of geography and history that carry individuals selectively to positions of power. The tardiness in relocating the meeting place of Parliament from Cape Town to Pretoria might owe something to the convenience and allegiances of the largest bloc in the party, but more fundamentally preserved in this 'distortion' are the ANC's own minorities of race. An evaluation of the ANC's argument that it is a multi-racial party cannot ignore the 'special case' of the Western Cape. This section of the leadership was one of the most volatile after the election, we note below.

A provincial 'skew' is neither precluded nor favoured by a party rule but emerges 'naturally' in the national leadership. An 'affirmative action' policy for Limpopo to raise 'its' number of representatives on the national list cannot be expected, for the same reasons that the national list is held to be exempt from the gender requirements otherwise prevailing (Pottie, p 211). Nevertheless, provincial identity is respected in the matter of replacements for departing members - those replacements in the period after 1999 maintained overall the distribution of the membership at the time of the 1999 election. This result might be expected in the case of provincial list members, to maintain the 'profile' of the provinces, as discussed, but in the case of the national list the same observed constancy requires a different explanation. Mere efficiency in maintaining constituency and electoral addresses across a parliamentary term might be sufficient to explain the 'custom' which, all the same, is based on certain, if possibly temporary, accommodations of local expectations. Though members generally are reported to be 'loosely assigned to constituencies across the country, if ... party whips so choose (Bridgman, p 71)', the ANC has, since the election, set a higher standard for itself, with attendant risks. A list system made to work with geographical accommodations sets expectations of the ANC as its managing party accordingly.

The identification of members with particular provinces was not necessarily a simple exercise, as almost any case will show. Thus Jacob Zuma's need to escape a continuing close identification with affairs in KwaZulu-Natal on his appointment as Vice-President in 1999 (when he also led the deployment committee of the NEC) left him a parliamentarian, and he had as much need as any to show a local identity, at least on occasion. Something akin to a nominal constituency in an old territory was not likely to bring benefit to him, however, so ANC lists and literature (including 
prominent pictorial identification) showed Zuma from 1999 in the Northern Cape - as far as it was possible to be from his former home. In most other cases it is equally clear that provincial identification in office and home location indicates an historical location in an area, from which the member concerned has built a base.

\section{GENDER}

The ANC's goal of one-third female representation in its organs was adopted at the party conference of December 1994, six months after the election delivered a female membership of almost $30 \%$ in the National Assembly, and was probably reached in mid-term with those who replaced some of the early departing members of the Assembly. By the 1999 election the party lists allowed a substantial increase from the position of 1994, augmenting the female membership of the caucus by more than twenty women members, the proportion overall reaching $36 \%$.

The proportion has increased slightly in the years since, following the pattern of new appointments reported generally in this paper, at least until the floorcrossings of March 2003 brought six members (all male) from the United Democratic Movement (UDM) and eight new appointments direct to ANC ranks to fill a then substantial number of vacancies. Table 4 summarises the period until then, distinguishing seniority, as between backbenchers and chairs of committees and whips, only for the current period when accurate data are available.

Women members have moved upwards as well an inwards - one to Cabinet and two to the deputy ministry - and more generally to positions as whips and committee chairs, to the extent indeed that the ANC backbench is greatly diminished as a pool of female talent for promotion. The period of floor crossing and new appointments brought numbers only to the backbenches and accentuated the party's problem with maintaining the balance there. Fewer than twenty women from the national list were still on the backbench by mid-2003, a proportion that barely met the party's requirements.

Critics have pointed to the dangers of fetishising parliamentary numbers, arguing that women's 'now close to equal participation in government [sic] has come at the price of weakening the mass-based women's movement that was the driving force behind SA women's move into Parliament' (Geisler 2000, pp 626-27), and, as far as the ANC is concerned, it is not unlikely that there might be a 'straightline' projection from 1994 to 1999 and beyond (which might achieve parity in about a decade). Equally, the ANC's performance is widely scrutinised, not least by international bodies that have identified female membership as a key objective (Myakayaka-Manzini April 2003). It is certain that the ANC is committed to more that the 'minimum' of a one-third quota in its representation in Parliament, where the party's control of the lists and a desire to overcome 'resistance' to the quota must lead to an attempt at exemplary action (ANC 10 May 2003).

The provincial parliaments are not a source of recruitment, however, as there are relatively few women members there. What was intended as a scale of 


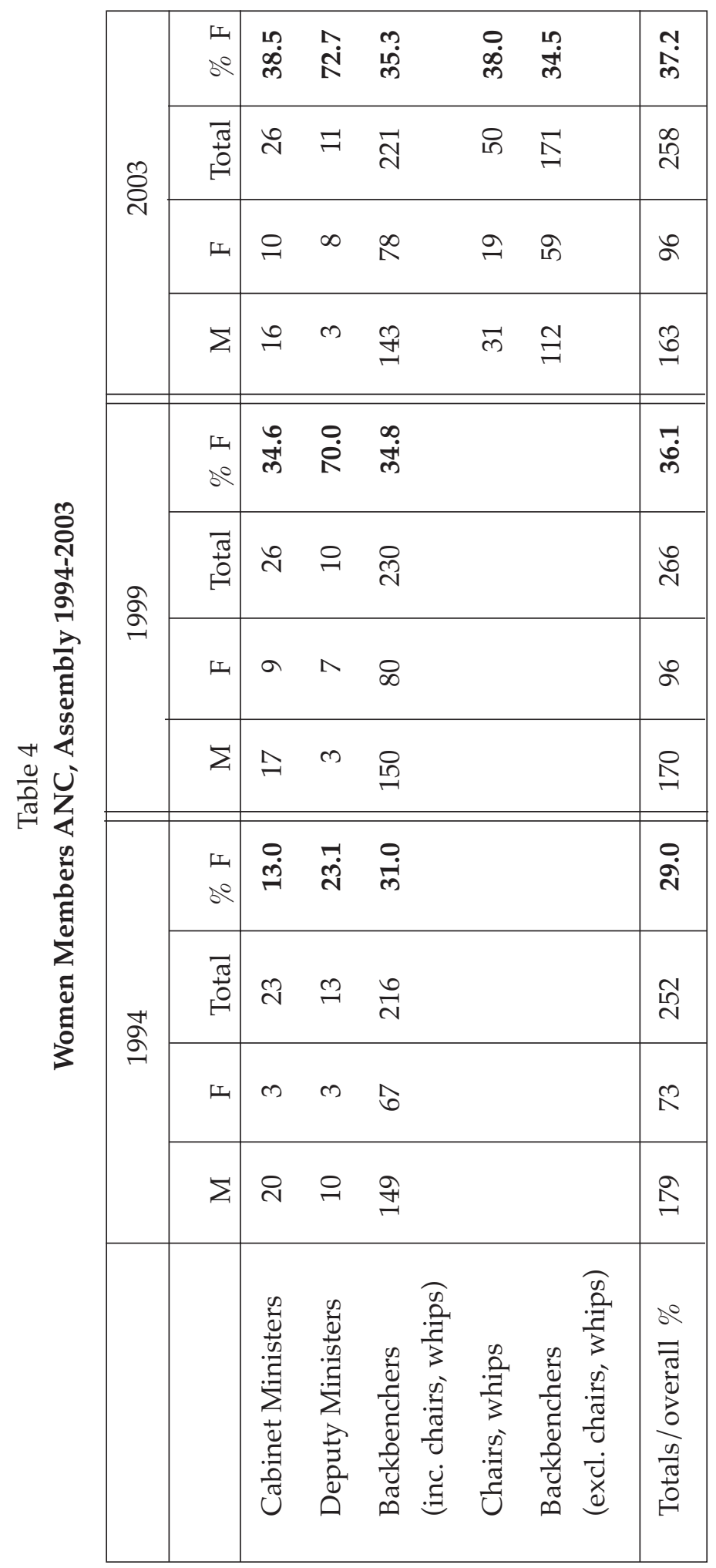


competence - from provincial to national parliaments, and from provincial to national lists in the Assembly - is stretched at both ends. The proportion of female members on the provincial list in 1999 reached 38.1\% and the national list only 32.3\%, giving support to the view that the provincial list is more easily managed for affirmative action than the national, where election is supposedly without regard to gender. It seems possible that an increased number of 'lateral appointments' will be made to the national list in the Assembly, with new members from civil society, perhaps, filling 'the vacuum that now exists between South African women and the parliamentarians who are expected to represent their interests' (Geisler, pp 626-27), or fulfilling 'commentary ... that the quiescence of ANC women MPs results from their allegiance to the party, their domination by male party bosses, and their need to retain their ranking in the list system to secure re-election' (Southall 2000, p165).

\section{The Former Members of 1999}

Of the ANC members of 1999, as noted, sixty had ceased to be members by May 2003. Death took seven, one of whom was murdered (it was questioned whether Robert Mkize, flagrantly shot dead by a police officer, was a political victim). The post-Assembly careers of the others are summarised in Table 5, distinguishing national and provincial lists.

Table 5

Former Members of the National Assembley: Career Moves

\begin{tabular}{|c|c|c|c|c|c|}
\hline & & National list & Provincial list & No. & $\%$ \\
\hline \multicolumn{4}{|c|}{ State \& Party Bureaucracy } & 16 & 30.2 \\
\hline Diplomats & 6 & 3 & 3 & & \\
\hline Govt Depts & 3 & 0 & 3 & & \\
\hline ANC Org & 7 & 2 & 5 & & \\
\hline \multicolumn{4}{|c|}{ NCOP, Prov \& Loc Govt } & 12 & 22.6 \\
\hline MECs & 5 & 3 & 2 & & \\
\hline Mayors & 4 & 1 & 3 & & \\
\hline NCOP & 3 & 2 & 1 & & \\
\hline \multicolumn{4}{|l|}{ Business \& Civic } & 6 & 11.3 \\
\hline Bus & 5 & 3 & 2 & & \\
\hline Civ & 1 & 1 & 0 & & \\
\hline \multicolumn{4}{|l|}{ Political Exits } & 16 & 30.2 \\
\hline 'Stormy' & 8 & 6 & 2 & & \\
\hline 'Managed' & 7 & 3 & 4 & & \\
\hline \multicolumn{2}{|l|}{ Uncertain } & 0 & 4 & 4 & 5.7 \\
\hline & & & & 54 & 100.0 \\
\hline
\end{tabular}


Positions in and around state and party organisations, especially in diplomacy and provincial government, were clear enough cases of 'deployment' in the conventional sense, even when some posts implied more the end than the flourishing of a reputation in the party. As with deployments from the NEC, diplomatic positions are reported to have been used to remove some dissidents, especially around the 'arms deal', though not all diplomatic postings can be so characterised.

Deployment to positions in the party apparatus were important at different levels - in leading roles (as with Ebrahim Ebrahim in Zuma's office and Malusi Gigaba with the Youth League), but also as a route for a number of women activists who had served in the first Parliament (Ela Gandhi, Ivy Gcina, Lizzie Abrahams, Elizabeth Phantsi) to 'step back' from parliamentary to party activity, to be replaced overall, as noted, by younger female members.

Deployments of this sort took place across national and provincial lists, as might be expected if largely 'tactical' decisions were being made about a member's fit with circumstances - for example in deployments to MEC positions where a regional identity was important - as with Nomatyala Hangana in the Western Cape and Frances Marshoff in the Free State. The aversion of national list members to executive positions in state organs was notable, but overall it seems clear that the party's deployment of its central cadre is a useful but limited tool of power.

If half the departures were 'official', almost as many clearly were not. These were 'stormy exits' of varying character. A few (Yengeni and Increase Ncinane, following convictions for financial offences) were disposed of through legal process, making them, in a narrow view, not political at all. More complicated fallings out left Phosa, Jay Naidoo and Z Pallo Jordan in ambiguous circumstances, but certainly still 'in politics', not least as members of the NEC.

Other departures on principle related to the crisis over the 'arms deal', some part of which was, it has been suggested, resolved by posting dissidents to diplomatic positions that were not negligible but were notably distant. Some, like Andrew Feinstein, departed for the private sector. Those reported as moving from Parliament, but without task announcement or later publicity, are classified here as 'managed exits'. Continuing extra-parliamentary work within the party, and possible re-emergence to public office, might not be precluded in these cases, but some fall from grace was implied. There are cases, no doubt, of 'deployment out' of elected office and public life. Many 'deployments' were forced upon the party rather than planned, and only about half of those reported were deployments in the sense that ANC policy demanded - largely to the party organisation and political and administrative positions in the provinces. The rest were mixtures of expediency, compromise and survival - not irrelevant characteristics in evaluating the nature and outcomes of intra-party dissent in the ANC. If about a score of the ANC caucus were more or less successfully deployed in the period, the scale of deployment seems to be less than critics imply. If rather more than that number left the Assembly for reasons other than 'deployment', issues of internal party democracy need both case-by-case and systemic investigation. 
The ANC is troubled politically both by the 'arms deal' and by the court decisions in the cases of Yengeni, Ncicane and, later, Madikizela-Mandela. Their wrongful use of parliamentary office 'proved' to some in the media that earlier allegations of possible corruption in the party were correct; to others that the ANC had weeded out some incompetent members; and to still others that the party had been forced to act, while leaving some members of doubtful quality in place. None of these suggestions seems well founded and, in this context, it seems preferable to support a more general conclusion, that 'opposition as behaviour has been ... extensive ... within the ruling party' (Southall 2001, p 275).

It is not clear that the casualties of politics were made easier by a list system that had replacements always ready. Redeployment is one thing, finding a replacement may be another. Since the election of 1999, the party has been required to find new members (taking provincial parliaments into account at the same assumed rate of turnover) at the rate of close to one a week. Replacements must be filtered through the requirements of parity of region (with regard also to provincial orientation even in the national list), and of better than parity in gender. The Assembly is the main site of deployment when the largest body of senior officials in the party is there, but the training and deployment of cadres at lower levels who are capable of promotion to their place are crucial issues for the party.

The sixty replacements considered here did maintain the national, provincial and gender profiles of the members elected in June 1999 with slight modification (an increase, as noted, in the proportion of female members overall) but lags between resignations and replacements could be prolonged - in the first year, the translation of a third of the replacements took more than three months, and in three cases more than six months, to effect. Vacancies were part of the system and, just before the floor-crossings of March 2003, had reached eight. These were small but not negligible numbers, and suggest that managing the system to find formally suitable replacements within Alliance identification has put strains on party capability.

\section{CONCLUSION}

One reading of the account above might reiterate the claim that the list system of voting allows 'the party leadership to place loyalists in key positions, and at the same time compensate those who have lost out in internal power struggles through redeployment to comfortable but less strategic posts' (Giliomee, Myburgh and Schlemmer, $\mathrm{p}$ 170). This view may, however, over rate the power of the leadership. The same authors ( $p$ 172) identify the ANC's ambitions in drawing up 'a comprehensive deployment policy and strategy' that would establish 'committees at national, provincial and local government level to oversee the deployment process and ensure that party members remain accountable after deployment' but these are the arrangements that the party has declared are functioning with difficulty. Southall's caution that the critics may 'overstate the capacity of the ANC to impose itself upon society' seems nearer the mark. The party's 'efforts to curb dissent may 
be interpreted as as much an indication of its weakness as its strength' (Southall 2001, p 282).

Any likely electoral strategy will present the ANC with problems in managing its dominant cadres, and more salient issues might include the balance of NEC membership between the national and provincial parliaments and local government, and the continued recruitment and training of entry-level cadres to provincial structures.

The ANC has frankly acknowledged its problems, and it cannot be said that a single line of policy characterises the party, or that one faction of its leadership is dominant to the exclusion of effective opposition on such issues as party recruitment and training, or the 'choice' of electoral and voting systems. This is not to deny that an executive decision, for example, could change the content of policy relatively quickly, but the issues of political mobilisation facing the ANC are not likely to be ameliorated by changes in, say, electoral processes. Problems of mobilisation are acute for all political parties - participation rates in elections appear to have been in steady decline since 1994 (Africa, Mattes, Herzenberg and Banda 2003, pp 4-5) but the ANC's attempt to reflect its ideology of equality in its parliamentary body presents special dilemmas. There may be opportunities for the organisations of civil society, and especially women's organisations, to fill a need in the party but mobilisation from any source must carry risks for an existing leadership.

Our study of the Assembly over a brief period of some four years cannot show that the ANC is able to operate a 'merit' system of recruitment and advancement, and there may be enough 'special cases' to show, at least, that some bad early decisions were made; but the overweening power of the presidential executive, though asserted, has been less than absolute, and compromise as much as conflict and banishment has marked the passage of many members through the Assembly. The making of the party lists for the 2004 election will show the next stage. 


\section{REFERENCES}

Adam, Heribert, Frederik Van Zyl Slabbert and Kogila Moodley. 1998. Comrades in Business: Post-Liberation Politics in South Africa. Utrecht: International Books. Africa, Cherrel, Robert Mattes, Collette Herzenberg and Lerato Banda. 2003. 'Political Party Support in South Africa: Trends since 1994'. Afrobarometer Briefing Paper No 63 May. http:// www.idasa.org.za/pdf/987.pdf

African National Congress (ANC). 12 January 2000. 'Commission on Cadre Policy,

Political and Ideological Work', Kwabwe, June 1985 sgopher:// gopher.anc.org.za:70/00/anc/history/kabcadre.txt>

— 7 May 2003. 'General Council: Mid-term Report and Review - Section 2: The ANC as a Movement that Organises and Leads the People in the Task of Social Transformation'.

- 10 May 2003. 'Transforming the State and Governance'. Umrabulo 16. http:/ /www.anc.org.za/ancdocs/pubs/umrabulo/umrabulo16/ tranformation.html

10 May 2003. 'Resolutions Adopted by the 51st National Conference ... on Women'. shttp://www.anc.org.za/ancdocs/history/conf/conference51/ resolutions.html>

Blais, André, Louis Massicotte and Agnieszka Dobrzynska. 1997. 'Direct Presidential Elections: A World Summary'. Electoral Studies 16(4).

Bridgman, Martha. 2002. 'Parliament, Foreign Policy and Civil Society in South Africa'. South African Journal of International Affairs 9(1), Summer.

Carr, Adam. 21 July 2003. 'Adam Carr's Electoral Archive: South Africa'. http:// psephos.adam-carr.net/southafrica/southafrica2.txt

Geisler, Gisela. 2000. " "Parliament is another Terrain of Struggle": Women, Men and Politics in South Africa'. Journal of Modern African Studies 38(4).

Giliomee, Hermann, James Myburgh and Lawrence Schlemmer. 2001. 'Dominant Party Rule, Opposition Parties and Minorities in South Africa'. Democratization 8(1), April.

Institute for Democracy in South Africa (Idasa). 1 May 2003. 'Floor-Crossing at a Glance' <wysiwyg://main.27/http://www.idasa.org.za/m main.php>

Klug, Heinz. 2000. Constituting Democracy: Law, Globalism and South Africa's Political Reconstruction. Cambridge: Cambridge University Press.

Kotze, Hennie. 2001. 'Institutionalising Parliament in South Africa: The Challenges to Parliamentary Leadership'. Acta Academica 33(1).

Myakayaka-Manzini, M. 2003. 'Women Empowered - Women in Parliament in South Africa'. In 'International IDEA Women in Politics: Women in Parliament: Case Studies', 2 April. http://www.idea.int/women/parl/studies5a.htm

Nijzink, Lia. 2001. 'Opposition in the New South African Parliament'. Democratization 8(1), April.

Nkomo, Joshua. 1983. The Story of My Life. London: Methuen. 
Pottie, David. 2001. 'The Electoral System and Opposition Parties in South Africa'. Democratization 8(1), April.

Reynolds, Andrew. 1999. Electoral Systems and Democratization in Southern Africa. Oxford: Oxford University Press.

Sechaba. August 1985. 'Let Us Act Together says President Tambo', p 14.

Southall, Roger. 1998. 'The Centralization and Fragmentation of South Africa's Dominant Party System'. African Affairs 97, October.

- 2000. 'The State of Democracy in South Africa'. Commonwealth and Comparative Politics 38(3), November.

— 2001. 'Conclusion: Emergent Perspectives on Opposition in South Africa'. Democratization 8(1).

- 2003. 'Democracy in Africa: Fragile and Necessary but Uncertain'. Journal of Contemporary African Studies 21(1), April. 